\title{
Influence of Demotivators on Acceptance of Technology: Challenges of Expatriate School Teachers while Imparting Online Teaching
}

\author{
Gokuladas V. K. and Baby Sam S. K. \\ Indian Schools Oman, Muscat, Sultanate of Oman \\ http://orcid.org/0000-0002-5177-4351 \\ http://orcid.org/0000-0002-7984-9167
}

\begin{abstract}
In the wake of the Covid-19 outbreak, academicians are resorting to technology-enabled remote learning to impart education. The main objective of this study is to identify those factors that could potentially demotivate educators at primary and secondary levels of education during the remote teaching process. This study will also look at the impact of these demotivators on the perception of educators regarding the technology-acceptance of E-learning and attitude towards E-learning. Data collected from 1174 school educators with respect to various challenges in E-learning and their acceptance of technology as an alternative mode of teaching have been analyzed through correlation and regression analysis. This study identified major Extrinsic and Intrinsic Demotivators that affect the performance of school educators while imparting education through remote teaching. The results showed that Perceived Usefulness and Perceived Ease of Use played a mediating role in the relationship between Extrinsic \& Intrinsic Demotivators and the Attitude towards E-learning. The outcome of this study is of greater relevance to the School Management Committees and the School Administration to appropriately strategize their plans to implement E-learning as an alternative mode of education in schools.
\end{abstract}

Keywords: Acceptance of Technology; Demotivators; E-learning; School Educators

\section{Introduction}

Technology has been of great assistance to many industries including education wherein considerable importance is being provided to students' centric education encompassing the way they aspire to learn. It has been playing a critical role in 21st-century education by assisting academicians to create, store, and disseminate explicit knowledge in the most efficient and accessible way (Oye, Salleh \& Noorminshah, 2011). Since most of the educational institutions are resorting to remote teaching through flip sessions owing to the Covid-19 outbreak, it is the time to address concerns made by researchers like Ehlers and 
Hilera (2012) that more empirical pieces of evidence are essential to understand the potential factors that could ensure the success of these remote sessions.

At this juncture, it is of greater research interest to identify those factors that could positively influence the successful implementation of e-learning or remote teaching process. In order to effectively roll out remote teaching programs, teachers need to be convinced and acquainted with the technology and its worthiness in imparting education in the best possible manner. In a study conducted by Banas and York (2017) among pre-service teachers, it was found that teachers' motivation such as intrinsic and extrinsic goal orientation developed through authentic learning process was one of the predictors of their intention to integrate technology for their instructional methods. For successful implementation of remote teaching, it is imperative that interactivity with students is maintained at the highest level. There are a number of other instructional methods such as the 'Trialogical' learning approach that have been found highly effective in imparting active and student-centered learning even in distant learning (Sansone, Cesareni, Ligorio, Bortolotti \& Buglass, 2019). Therefore, educators also need to be conversant with technologies such as blogs, discussion forums, virtual meetings, etc., so as to ensure that they successfully deliver the sessions through remote teaching (Hadad, 2007). These studies point to the fact that remote teaching would be highly effective when it is properly designed and utilized.

At the same time, it is a matter of great concern for educators whether they would be successfully utilizing the E-learning technology to perform their functions. One of the reasons for this apprehension could be the feeling among most of the educators about their capability to utilize the technology most of them were taking technological assistance in teaching for the first time in their professional life. Ward, Peters \& Shelley (2010) observed that while imparting E-learning, faculty had concerns about the technical features of the Learning Management System or other educational related technologies. Teaching online could also influence image beliefs of faculty whereby they experienced the feeling of inferiority while conducting online courses as compared to the traditional classroom (Allen \& Seaman, 2015). Wingo, Ivankova and Moss (2017) revealed faculty were concerned that their perceptions such as the effectiveness of online classes towards students' success, the requirement of technical supports, expected extra workload, managing online classes, etc., could be detrimental to their job performance. These apprehensions would not only affect their performance but also result in low motivation and job satisfaction among educators. Therefore, identification of those factors that influence educators in their pursuit of imparting online education would help school administrators to adopt appropriate strategies for successful implementation of remote teaching. The main objective of this study is to identify those factors that could potentially demotivate educators at primary and secondary levels of education during the remote teaching process. This study will also look at the impact of these demotivators on the perception of educators regarding the technology-acceptance of E-learning and attitude towards E-learning. 


\section{Review of related literature}

\subsection{Theoretical Framework}

The Motivation-Hygiene Theory proposed by Herzberg depicts two factors i.e., the factors that result in motivation or job satisfaction and the factors that could result in job dissatisfaction (Herzberg, Mausner \& Snyderman, 2017). This theory proposes that these factors motivate individuals to perform better and attain job satisfaction would be different from those factors that demotivate them leading to job dissatisfaction. On the other hand, there is Expectancy Theory proposed by Vroom (1964) which postulates that people act consciously and rationally in their job so as to ensure that they get the right rewards for the same. In other words, individuals are generally driven not only by inherent motivations but also by stimulus from external sources that help them to achieve their professional objectives. In view of the above these theories, it could be reasonably assumed that while the employees work towards the goal with full efforts and commitment, there could be certain factors that could motivate and demotivate them during the course. It is the ability of an individual to overcome those demotivators through the help of those motivating factors that will ultimately decide the success of the employees in their profession.

\subsection{Demotivators}

Similar to the concept of motivators that help individuals to perform better, there could be demotivators that hinder such development. However, there are fewer studies that researched extensively on demotivators as compared to that of the studies on motivators. This is quite evident in the education sector as fewer studies are carried out on demotivators related to remote teaching. These demotivators could potentially affect the dissatisfaction of teachers with respect to their profession leading to weak learning outcomes (Hettiarachchi, 2013). Johnson (2000) observed that the flexibility of teaching conditions and the corresponding curriculum that matches the teaching needs could prevent the demotivation of educators. Low-quality teaching resources also contribute to the demotivation of teachers which in turn resulted in low performance (Menyhárt, 2008). Barın, Turgay and Sahin (2018) also identified that extrinsic factors such as teaching facilities, school administration, and the curriculum could adversely influence the motivation of educators. It was also identified that demotivators could result in a lack of self-motivation. Han and Yin (2016) identified that the relationships with and qualities of colleagues played an important role in motivating or demotivating teachers at the workplace.

\subsubsection{Intrinsic and Extrinsic demotivators}

Another dimension of the concept of motivation is whether it is intrinsically or extrinsically motivating or demotivating. Ryan and Deci (2000) argued that motivation has its own role in the field of education because motivation in this field is related to various actions and intentions. They also observed that while intrinsic motivation reflected the natural human propensity to learn and integrate, extrinsic motivation was roused as a result of external control with considerable variation. Intrinsic motivation such as enjoyment, excitement, and attachment towards a job would positively influence the effectiveness of the job. Also, any factor would be considered as intrinsic when the external supports are not required for the learner to continue the activity. Gange and Deci (2005) 
identified that intrinsic reasons were more dominant than extrinsic reasons as far as the participation of the individuals in activities was concerned. The motivational factors for teaching fraternity could either help the educator to perform exceptionally well. Even though the E-learning system currently being followed by various educators to impart education during these trying times has the advantage of connecting people from any part of the world (Kim, 2006), the readiness of the educator was the crucial fact for the success of remote teaching (Teddy So \& Swatman, 2010).

Seaman (2009) observed that faculty performed well in online teaching when they were trained, supported, and mentored appropriately. Sansone, Cesareni, Ligorio, Bortolotti and Buglass (2019) identified that training programs conducted through specific roles by the participants resulted in creating positive perceptions of collaborative learning as well as the use of technology in classrooms. Faculties were also found positive about using technology to impart education when they saw it as an avenue for professional development (McQuiggan, 2012; Panda \& Mishra, 2007). On the other hand, it was observed in the study conducted by Barton and Haydn (2006) that just providing adequate information might not be ideal to develop the competencies of teachers in using Information and Communication Technology facilities as observed by the trainee teachers. Erkaya and Rocha (2013) suggested that teachers remain unaffected by the negative external factors when they are intrinsically motivated. Some of the motivators for online teaching faculty are flexible work schedules (Shea, 2007) and the flexibility of online instruction (Green, Alejandro \& Brown, 2009).

On the other hand, factors such as include inadequate technical support, increased workload, not having enough time to prepare, concern about course quality, feeling of not-being technically competent, and concern over the quality of students' work could demotivate educators in online teaching (Cook, Ley, Crawford \& Warner, 2009). Glanz (2014) identified excessive time commitment in online teaching was one of the top demotivators for teaching fraternity. In the online mode of teaching, educators were apprehensive about the possibility of continuous communication with students in order to track the activities of the students (Glanz, 2014). However, intrinsic factors appeared to be more influential than extrinsic factors on educators. Increased workload has been identified as one of the top demotivators for educators in remote teaching (Shea, 2019; Lloyd, Byrne \& McCoy 2012; Alsofyani, Aris, Eynon \& Majid, 2012). The extra-time that educators used for the preparation of their online session had adversely affected some of them (Chapman, 2011).

It was suggested by Ertmer and Ottenbreit-Leftwich (2012) that when teachers change their approach from technology integration to technology-enabled learning through implementing powerful instructional methods, they would be in a better position to engage the students in a more meaningful and relevant learning environment. At this juncture, the concept of learning motivation proposed by Gardner and Lambert (1972) appeared to be relevant even though it was related to language acquisition. According to them, there are two types of learning motivation i.e., instrumental motivation and integrative motivation. 
While instrumental motivation denoted learning the language as an instrument to achieve career goals, integrative motivation reflected the passion to learn a language to interact with that culture effectively. Similarly, the need of the hour is the integrative approach on the part of teachers to assimilate the technological advancement to the teaching process rather than the instrumental approach just to equip them to deal with the challenges of remote teaching.

Bolliger and Wasilik (2009) observed that the satisfaction of online teaching faculty was influenced by institutional issues such as higher workload and increased time commitment. Educators feel reluctant to online teaching mainly because of the fear of change, workload issues, quality of learning outcomes, and concerns about technological assistance (Bacow, Bowen, Guthrie, Long \& Lack, 2012; Betts \& Heaston, 2014). Training educators in E-learning facilities did enhance their satisfaction (Lackey, 2011). Lee (2001) observed that educators required strong institutional support in various forms to run the E-learning effectively since technical issues were found to be adversely affecting the satisfaction of teachers (Bolliger \& Wasilik, 2009). Allen and Seaman (2015) observed that concern about the quality of teaching through online could also adversely influence educators.

\subsection{Perceived Ease of Use and Perceived Usefulness}

Technology Acceptance Model (TAM) proposed by Venkatesh and Davis (2000) stipulated that Perceived Ease of Use and Perceived Usefulness are predictors of the acceptance behavior of people towards technology. TAM has been proved to be successful in identifying the acceptance of technology by knowledge workers including educators (Lee, Kozar \& Larsen, 2003). King and He (2006) identified through a meta-analysis that TAM was a powerful predictive model that could be applied to various contexts. BurtonJones and Hubona (2005) asserted that the end-users of technology would develop cognitive responses based on their perceptions of usefulness and ease of use of technology. These responses would in turn result in the development of a corresponding attitude towards acceptance of technology and further behavioral intentions. It was also observed that PU is a significant predictor of attitude towards the acceptance of technology and further behavioral intention (Wong et al., 2013).

\subsection{Attitude towards Technology}

Schechter (2000) asserted that the comfort and proficiency of teachers with the technology would positively influence the use of technology and further usage in the classroom. The attitude of teachers does influence the infusion of technology into the classroom environment (Demetriadis et al., 2003). There are few variables that contributed to the attitude of teachers towards technology such as experience in teaching, gender, and subjects handled (Jimoyiannis \& Komis, 2007). ChanLin (2005) identified that teachers who possessed creativity were more likely to absorb the technology for imparting education and were also influenced by factors such as learning environment and curriculum-related issues. It has been identified that the attitude of teachers towards technology acceptance would also be influenced by their familiarity with the usage of technology (Teo, Lee \&Chai, 2008). 


\section{Conceptual Model and Hypotheses}

The research conceptual model proposed in this study is as given in Figure 1.

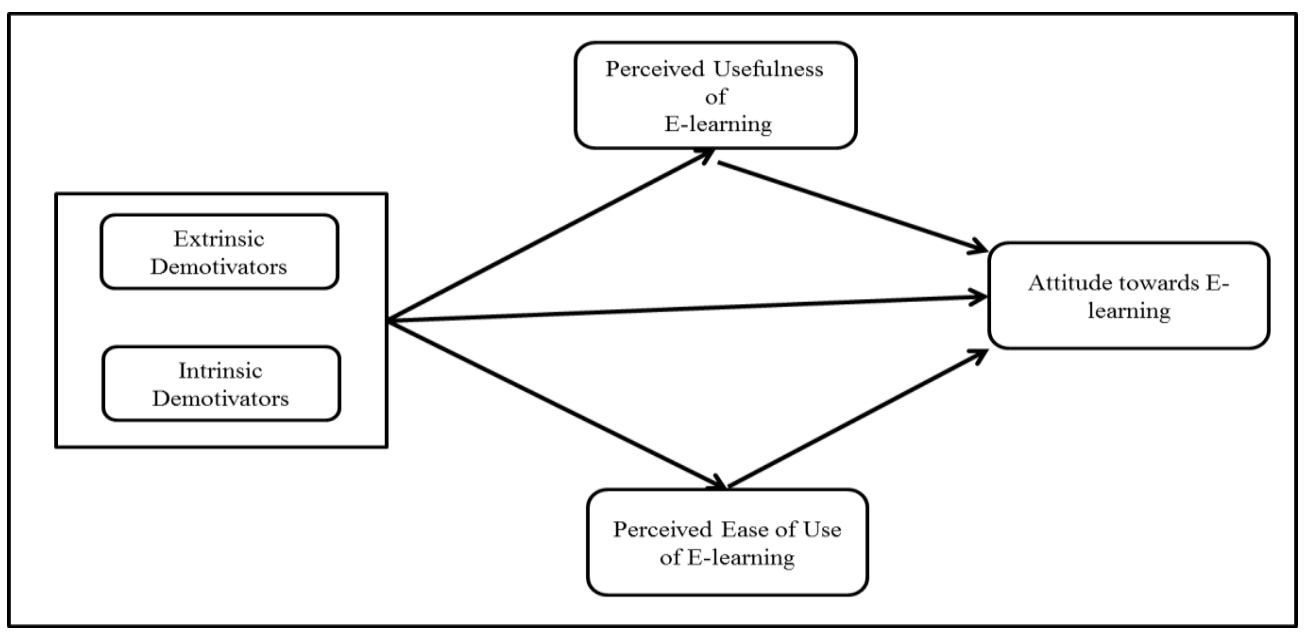

Figure 1 - Research Model

We defined demotivators as those factors that could potentially influence the teachers negatively during the process of handling sessions through remote learning. We also categorized these demotivators into two categories i.e., extrinsic demotivators and intrinsic demotivators. We classified factors such as 'technical interruptions during E-learning sessions', 'low bandwidth of internet connectivity', 'long-preparatory works before each session', 'low-control over students during E-learning sessions', and 'lack of technical know-how' as the main extrinsic demotivators. Factors such as 'the feeling of low-connectivity with students', 'perceived lack of physical presence', 'feeling of not being able to provide hands-on experience', 'perceived difficulty in carrying out assessments online', and 'perceived difficulty in getting feedback' are categorized as intrinsic demotivators. While Perceived Usefulness denoted as the usefulness of the Elearning process for imparting teaching, Perceived Ease-of-use reflected the easiness of handling E-learning sessions. Past research has identified that perceived ease-of-use and perceived usefulness had significant positive predictability in developing attitudes towards usage of technology which is categorized as the attitude towards E-learning.

Ghanghesh (2013) pointed out the intrinsic factors could also include a good relationship with people and job responsibility. It was also identified that intrinsic motivation exercised more influence than extrinsic motivation on the job performance of teachers. Such a positive influence of intrinsic motivation could in turn result in a better workplace attitude (Thatcher, Liu \& Stepina, 2002). Boekaerts (2001) observed that an individual's behavior is influenced by two types of motivation i.e., intrinsic and extrinsic motivation. Teo, Wong and Chai (2009) observed that behavioral intention towards computers by teachers was significantly influenced by the Perceived Usefulness (PU) and Perceived Ease of Use (PEOU). In view of the above, the following hypotheses have been proposed in this study. 
H1: Extrinsic and intrinsic demotivators will have significant negative relationships with the perceived usefulness of the E-learning process among school educators.

H2: Extrinsic and intrinsic demotivators will have significant negative relationships with perceived ease-of-use of the E-learning process among school educators.

H3: Extrinsic and intrinsic demotivators will have significant negative relationships with the attitude towards the E-learning process among school educators.

Davis (1989) proposed the Technology Acceptance Model which postulates that the attitude of an individual towards technology is influenced by the Perceived Ease-Of-Use (PEOU) and Perceived Usefulness (PU) of the technology. Ma, Andersson and Streith (2005) explained that the intentions to use technology by educators were significantly influenced by their perceived usefulness of the technology. Therefore, we propose the following hypotheses also in this study.

H4: Perceived ease-of-use of the E-learning process will have a significant positive relationship with the attitude towards the E-learning process among school educators.

H5: Perceived usefulness of the E-learning process will have a significant positive relationship with the attitude towards the E-learning process among school educators.

\section{Methodology}

\subsection{Sample}

As one of the consequences of the Covid-19 outbreak, academicians across the globe have been prompted to switch over to the online mode of teaching for a prolonged period, probably for the first time in their professional life. Even though educators in the field of higher education might have had the experience in remote teaching occasionally, most of the school educators must have been experiencing this phenomenon for the first time. Therefore, we approached 2400 school educators of Indian origin who are remotely teaching expatriate Indian students in the Sultanate of Oman with a self-administered questionnaire. We resorted to a simple random sampling method as this was the only approach of data collection possible during this pandemic period. We received a total of 1174 correct responses after having eliminated duplicates through IP address.

\subsection{Demographic descriptive}

Out of 1174 respondents, 946 are females and 228 are males which form $80 \%$ and $20 \%$ respectively. In this study, we categorized the respondents into four categories on the basis of their age i.e., within the age bracket of ' 20 to 30 ', ' 31 to 40 ', ' 41 to 50 ', and 'above 50 years'. While $6 \%$ of the respondents belonged to the age bracket of 20 to 30, 459 of them belonged to the age bracket of 31 to 40 . The biggest number of respondents belonged to the category of 41 to $50(40.9 \%)$ whereas the category of above 50 years of age consisted of only $14 \%$ of the respondents. 599 respondents (51\%) are imparting education in rurally located 
schools whereas $575(49 \%)$ of them are belonging to schools located in urban areas of the country.

As far as the teaching level of the respondents is concerned, KG level represented 10\%, Primary level with 32\%, Middle level with $26 \%$, Secondary level with $14 \%$, and Senior secondary with $18 \%$ respectively. This representation shows that schools are adequately fulfilling the remote learning requirements of all sections of students. With respect to the educational qualifications of the respondents, $68 \%$ of them possess post-graduate degrees and $28 \%$ of them are graduates. The details of the demographics of the respondents are summarized in Table 1.

Table 1. Demographic profile

\begin{tabular}{llll}
\hline Measure & Items & Frequency & Percent \\
\hline Gender & Female & 946 & 80.6 \\
Age_Group & Male & 228 & 19.4 \\
& 20 to 30 & 70 & 6.0 \\
& 31 to 40 & 459 & 39.1 \\
& 41 to 50 & 480 & 40.9 \\
Location & Above 50 & 165 & 14.1 \\
& Rural & 599 & 51.0 \\
Teaching level & Urban & 575 & 49.0 \\
& KG & 115 & 9.8 \\
& Primary & 374 & 31.9 \\
& Middle & 307 & 26.1 \\
& Secondary & 165 & 14.1 \\
& Senior Secondary & 213 & 18.1 \\
Educational & & & \\
& Trained Teacher & 35 & 3.0 \\
& Graduate & 333 & 28.4 \\
& Post Graduate & 798 & 68.0 \\
& Doctorate & 8 & .7 \\
\hline
\end{tabular}

\subsection{Measurement Tools}

The items (Davis, 1989, Table 6, p. 329) for measuring Perceived Usefulness (PU) and Perceived Ease-Of-Use (PEOU) (revised 10 items each from the earlier original 14 items scale) were adopted as part of the questionnaire. These items were reported to have construct validity through multitrait-multimethod and factor analysis (Davis, 1989). In order to measure the Attitude towards Elearning, another 5 items on a seven-point scale developed by Ajzen and Fishbein (1980) that measured five different types of attitudes were adopted in this study. Based on the review of the literature, we also categorized the number of extrinsic and intrinsic demotivators and scored them as per the number of such demotivators experienced by the educators ( 0 for 'no difficulties', 1 for one difficulty experienced, and so on till 5 as we have categorized maximum of five 
such demotivators as extrinsic and intrinsic factors. All these items have been displayed in Appendix A.

\section{Results}

\subsection{Descriptive Statistics}

Descriptive analysis of variables under this study has revealed that the respondents have scored above average level in respect of Perceived Usefulness and Perceived Ease of Use (3.1 and 3.26 respectively). In the case of Attitude towards E-learning also the mean score is well above the average marking. On the other hand, the respondents experienced fewer difficulties as far as both extrinsic and intrinsic motivators are concerned. However, it has been observed that the educators experienced more of intrinsic challenges than that of the extrinsic factors. In other words, these are indicators that it is more of psychological difficulties that bothered the educators than technical difficulties in running the E-learning process. The details of descriptive statistics are as given in Table 2.

Table 2. Descriptive Statistics (Means and S.D)

\begin{tabular}{lll}
\hline \multicolumn{1}{r}{$n=1174$} & Mean & S.D \\
\hline Extrinsic_Demo & 1.59 & .962 \\
Intrinsic_Demo & 1.84 & 1.131 \\
PU & 3.10 & .826 \\
PEUS & 3.26 & .616 \\
ATTITUDE & 5.29 & 1.125 \\
\hline
\end{tabular}

\subsection{Reliability}

Cronbach's Alpha Reliability analysis has been carried out in respect of all 25 items (10 items each for PU \& PEOU, and 5 items for Attitude towards Elearning) that confirmed the coefficient of .91 for these items. According to Cortina (1993), this range of co-efficient is an excellent level of acceptance.

\subsection{Analysis}

As far as the extrinsic demotivators are concerned, 53\% of the respondents felt that Technical Interruption during the session was the primary challenge for them. This is followed by Low bandwidth issues (40\%), long technical preparation time (33\%), less control over students during remote teaching $(30 \%)$, and operational discomforts of being not-so-tech-savvy (12\%) as major extrinsic challenges faced by the teachers in online-education. The details are as given in Figure 2. 


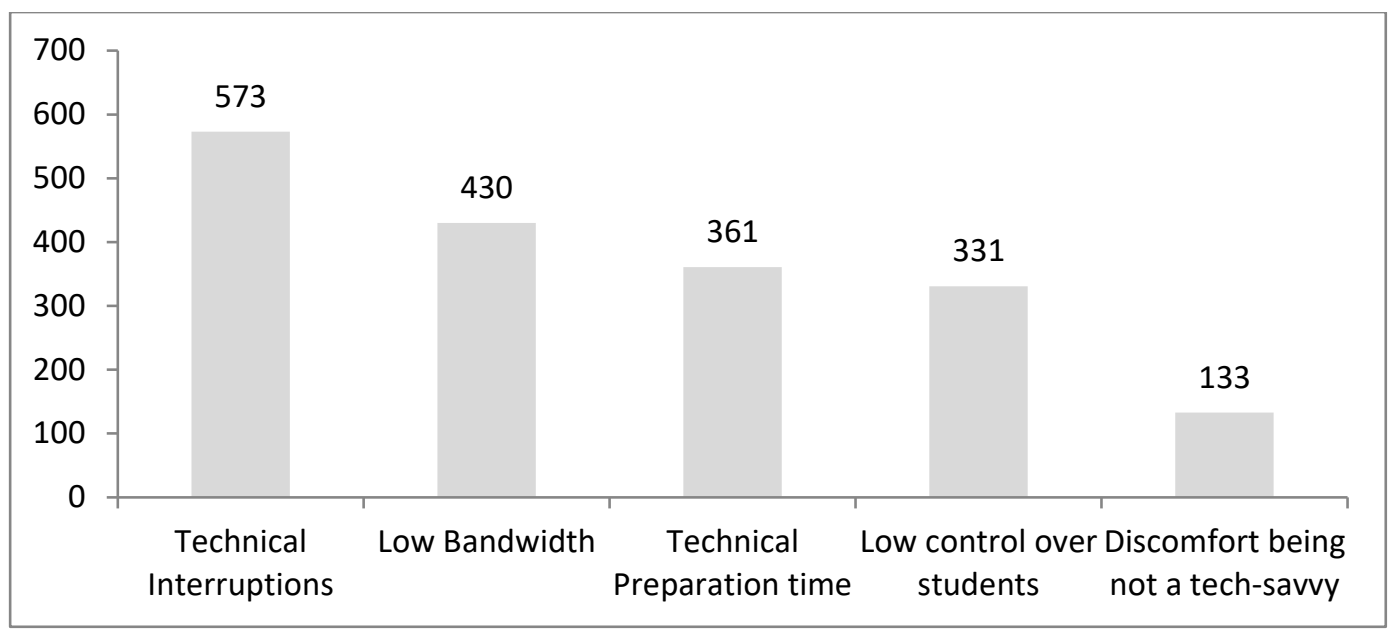

Figure 2 - Major extrinsic challenges of teachers in online teaching

At the same time, there are also some intrinsic challenges being faced by these teachers in online education. These are explained in Figure 3. A whopping 75\% of the teachers felt that low-connectivity with the students through remote teaching was their major challenge in remote teaching. This is followed by challenges in teaching specific subjects that require more of the physical presence of the teacher $(40 \%)$, lack of hands-on teaching $(35 \%)$, difficulty in assessments (30\%), and the lack of feedback from students (16\%). This result showed that lack of sufficient feedback from students through remote teaching aggravated the concerns of educators which otherwise would have been minimal in a traditional classroom.

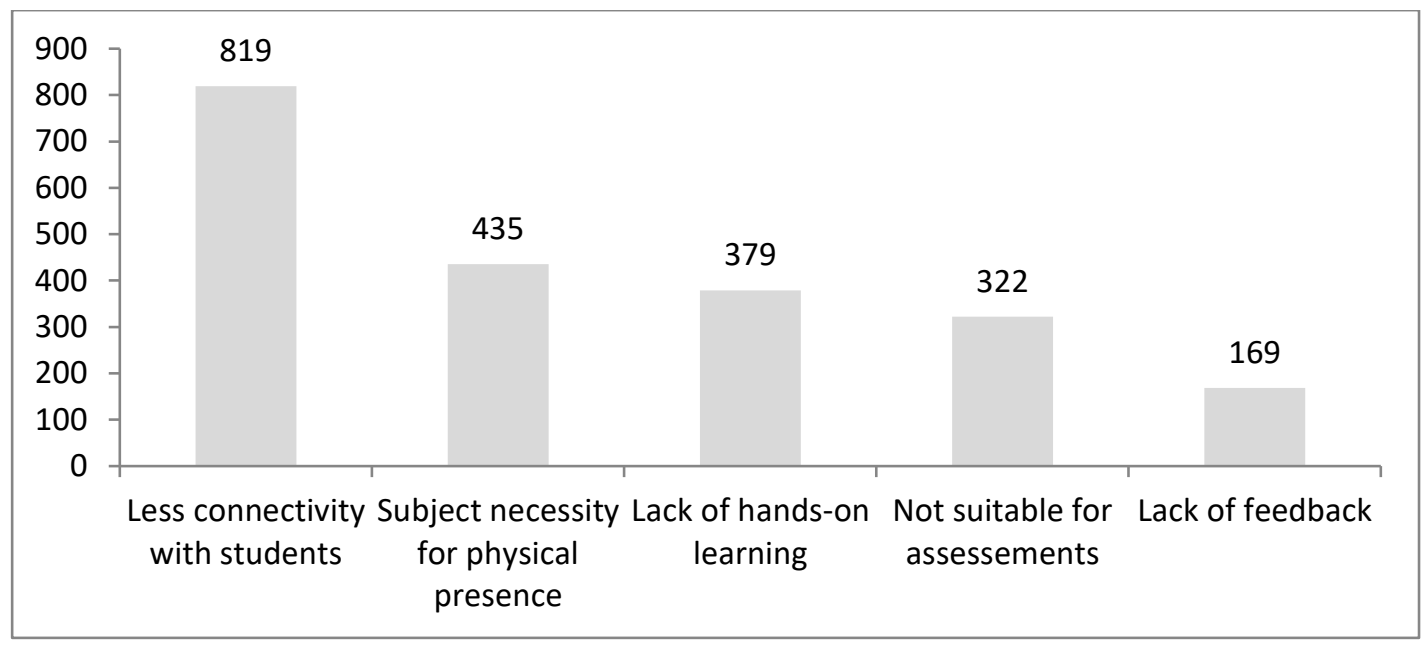

Figure 3 - Major intrinsic challenges of teachers in online teaching

Correlation analysis was performed on the research variables and the output of the same is as provided in Table 3. All the research variables have been found to be significantly related to each other. A statistically significant a moderate-tostrong positive relationship was observed among the three research variables of technology acceptance i.e., perceived ease of use of E-learning, perceived usefulness of E-learning in imparting education, and attitude towards E-learning $(r=.60, p<.0001)$. This indicates that with the increase in the perceived ease of 
use and perceived usefulness of E-learning, it is very likely that the positive attitude towards E-learning will also be developed. Yet another dimension in this correlation analysis is the significant moderate positive relationship between intrinsic demotivators and extrinsic demotivators $(r=.59, p<.0001)$. This shows that any incremental changes in the number of intrinsic demotivators are likely to result in a corresponding increase in extrinsic demotivators. A probable cause for this positive relationship could be the result of the frustration of educators having encountered challenges of varying degrees while negotiating them. As far as the relationship between demotivators and the research variables are concerned, it has been observed that the demotivators exhibited a significant negative relationship with research variables ( $r$ ranging from -.24 to -.35, $p<$ .0001). However, it is also important to note that extrinsic demotivators exhibited a significant negative relationship with perceived ease of use than intrinsic demotivators whereas intrinsic demotivators showed a significant negative relationship with perceived usefulness than extrinsic demotivators. This shows that the lesser the extrinsic demotivators, the higher will be perceived ease of use. Similarly, the lesser the number of intrinsic demotivators, the higher will be the perceived usefulness of E-learning. Demotivators were also observed to be having a weak negative significant relationship with the attitude towards E-learning.

Table 3. Correlation Analysis

\begin{tabular}{lcccc}
\hline & Extrinsic_Demo & Intrinsic_Demo & PU & PEUS \\
\hline Intrinsic_Demo & $.588^{* *}$ & & & \\
PU & $-.311^{* *}$ & $-.334^{* *}$ & & \\
PEUS & $-.350^{* *}$ & $-.277^{* *}$ & $.604^{* *}$ & \\
Attitude & $-.268^{* *}$ & $-.239^{* *}$ & $.605^{* *}$ & $.601^{* *}$ \\
\hline
\end{tabular}

**. Correlation is significant at the 0.01 level (2-tailed).

\subsection{Discussion}

In order to get further insight into these relationships, regression analyses were performed to test the hypotheses proposed in this study. First, we conducted a multiple regression model with Attitude towards E-learning as a dependent variable and the rest of the research variables as independent variables. The results of the regression indicated the predictors explained $45.2 \%$ of the variance $\left(R^{2}=.45, F(4,1174)=242.998, p<.0000\right)$. It was found that both Perceived Usefulness and Perceived Ease of Use significantly predicted Attitude towards E-learning $(\beta=.51$ and $\beta=.67$ respectively, $p<.000$ ). This is placed in Table 4 . Thus, hypotheses $\mathbf{H 4} \mathcal{E} \mathbf{H} 5$ which postulated that Perceived Usefulness and Perceived Ease of Use respectively will have a positive relationship with Attitude towards E-learning have been supported in this study.

Subsequently, regression models that had Perceived Usefulness and Perceived Ease of Use as dependent variables and Demotivators as independent variables have also been developed and placed in Table $5 \& 6$ respectively. With regard to the model with Perceived Usefulness as the dependent variable, the regression model reported $F(2,1174)=88.623, p<.0000)$ and model with Perceived Ease of 
Use as the dependent variable, the regression model reported $F(2,1174)=87.900$, $p<.0000)$. It was found that both Extrinsic Demotivators $(\beta=-.15, \mathrm{p}<.000)$ and Intrinsic Demotivators $(\beta=-.17, p<.000)$ significantly predicted Perceived Usefulness. Similar findings were also observed with respect to Perceived Ease of Use wherein both Extrinsic Demotivators $(\beta=-.18, \mathrm{p}<.000)$ and Intrinsic Demotivators $(\beta=-.06, p<.000)$ significantly predicted Perceived Ease of Use. These findings not only supported hypotheses $H \mathbf{H} \& \mathbf{H} 2$ which proposed that Extrinsic and Intrinsic demotivators will have a significant negative relationship with the Perceived Usefulness and Perceived Ease of Use of E-learning but also revealed the mediating role of Perceived Usefulness and Perceived Ease of Use in controlling the effect of Demotivators on the dependent variable Attitude towards E-learning of school educators. However, $\mathbf{H} \mathbf{3}$ which postulated that Extrinsic and intrinsic demotivators will have a negative relationship with the attitude towards the E-learning process among school educators has not been supported in this study.

Table 4. Regression Analysis - Attitude towards E-learning as a dependent variable

\begin{tabular}{llccccc}
\hline & \multicolumn{2}{c}{ Unstandardized } & \multicolumn{2}{c}{ Standardized } & & \\
Model & & $\mathrm{B}$ & Std. Error & Beta & $\mathrm{T}$ & Sig. \\
\hline 1 & (Constant) & 1.558 & .167 & & 9.310 & .000 \\
& PU & .514 & .038 & .377 & 13.576 & .000 \\
& PEUS & .668 & .051 & .365 & 13.156 & .000 \\
& Ex_Demo & -.028 & .032 & -.024 & -.871 & .384 \\
& In_Demo & .002 & .027 & .002 & .067 & .946 \\
\hline
\end{tabular}

a. Dependent Variable: ATTITUDE

Table 5. Regression Analysis - Perceived Usefulness of E-learning as a dependent variable

\begin{tabular}{llccccc}
\hline \multicolumn{2}{c}{ Model } & & \multicolumn{2}{c}{ Unstandardized } & \multicolumn{2}{c}{ Standardized } \\
\hline 1 & (Constant) & 3.650 & .047 & & 77.412 & .000 \\
& Ex_Demo & -.151 & .029 & -.176 & -5.222 & .000 \\
& In_Demo & -.168 & .025 & -.230 & -6.837 & .000 \\
\hline
\end{tabular}

a. Dependent Variable: PU

Table 6. Regression Analysis - Perceived Ease of Use of E-learning as a dependent variable

\begin{tabular}{|c|c|c|c|c|c|c|}
\hline \multirow[b]{2}{*}{ Model } & & \multicolumn{2}{|c|}{ Unstandardized } & \multicolumn{2}{|l|}{ Standardized } & \multirow[b]{2}{*}{ Sig. } \\
\hline & & $\mathrm{B}$ & Std. Error & Beta & $\mathrm{t}$ & \\
\hline 1 & (Constant) & 3.666 & .035 & & 104.301 & .000 \\
\hline & Ex_Demo & -.183 & .022 & -.286 & -8.498 & .000 \\
\hline & In_Demo & -.059 & .018 & -.109 & -3.237 & .001 \\
\hline
\end{tabular}

a. Dependent Variable: PEUS

In view of the above findings, the predictive model of hypothesized relationships among variables is as given in Figure 4. 


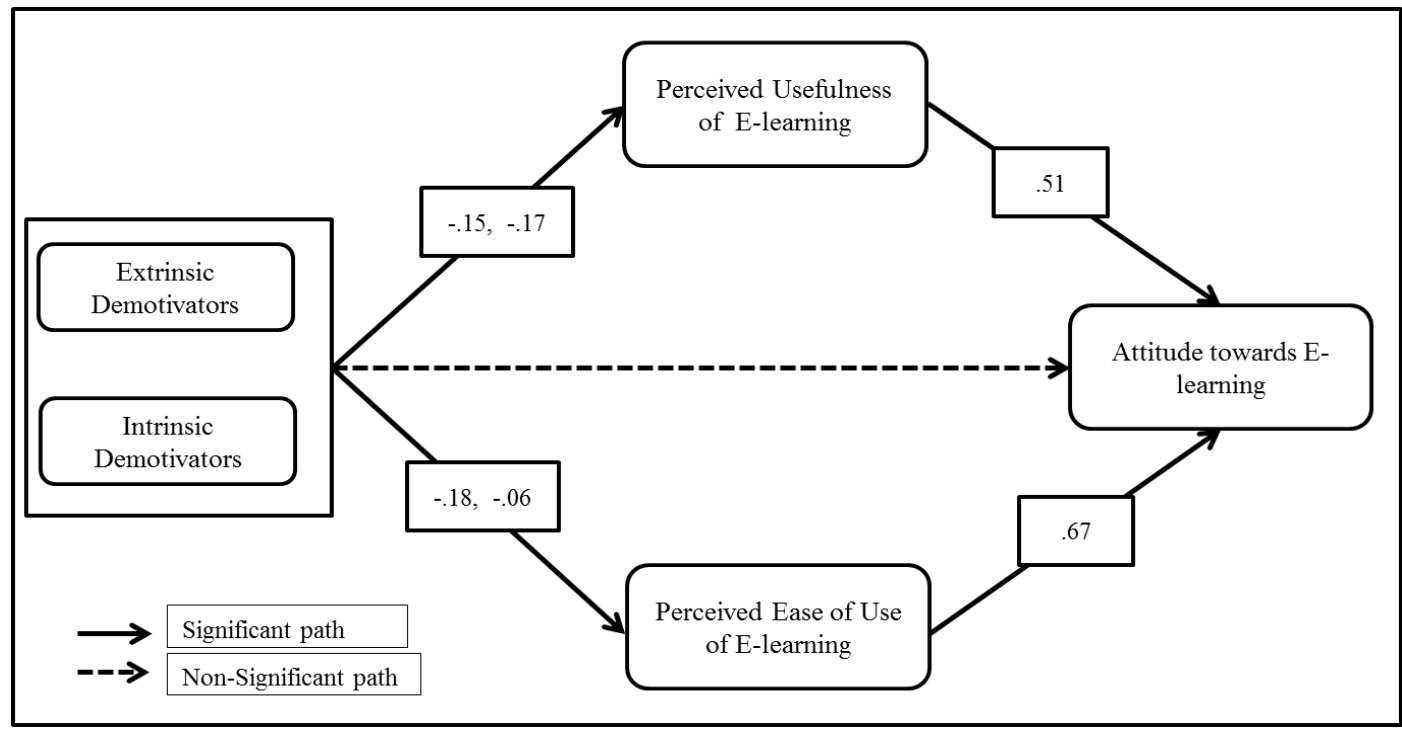

Figure 4 - Relationship among variables

\section{Conclusion}

A model to understand the influence of Extrinsic and Intrinsic demotivators on the Technology Acceptance variables has been presented and validated in this study. There are several implications of this empirical output which are explained in succeeding paragraphs. First, demotivators play an influential role in the morale of educators. While challenges such as technical interruptions and low bandwidth could be tackled through organizational support, various training programs could result in better acceptance of technology as identified by Sansone et al., (2019). Acquainting with the technology through such training programs could mitigate such feelings of not getting connected with students more realistically. In this study, we identified that the lesser the number of demotivators, be it extrinsic or intrinsic, the greater will be the perceived usefulness and the perceived ease of use of technology by educators for conducting online teaching. While the majority of the extrinsic demotivators could be tacked through administrative actions by the school management, adequate counseling and training programs could help the teachers to overcome the intrinsic challenges of imparting education through remote teaching. Second, though we identified that demotivators had a negative correlation with all other research variables, these demotivators did not have any direct influence on the Attitude towards the E-learning of educators. However, mediation by Perceived Usefulness and Perceived Ease of Use on the relationship between demotivators and Attitude towards E-learning emphasized the importance of TAM in the educational sector when there is a paradigm shift in the teaching process. Therefore, blended learning, integration of face-to-face teaching \& online approaches (Graham, 2006), and adopting innovative learning approaches such as the 'Trialogical' learning approach (Sansone et al., 2019) would be effective and flexible processes through which transformative changes could happen in the field of education (Hancock \& Wong, 2012). The findings of this study would pave the way for educational institutions to chalk out different strategies to minimize the demotivators so as to ensure that academicians take 
the education to the next level of technology-assisted teaching and learning. Various Extrinsic and Intrinsic demotivators identified in this study would be of greater relevance to the educational institutions which venture into E-learning as an alternative mode of interacting with students.

\section{Limitation and Future Scope of this Study}

This study focused only on teachers of primary and secondary education. A comparative study involving faculty in higher education institutions will provide further insights into various differing challenges being faced by these educators while implementing remote teaching. Another limitation of this study is that the participants of this study were the expatriate teachers of Indian origin. A detailed study involving native teachers is likely to provide various challenges of E-learning in the context of culture.

\section{References}

Ajzen, I., \& Fishbein, M. (1980) Understanding attitudes and predicting social behavior, Englewood Cliffs, NJ: Prentice-Hall. Retrieved from https://ci.nii.ac.jp/naid/10011527857/

Allen, I. E., \& Seaman, J. (2015). Grade Level: Tracking Online Education in the United States. Babson Survey Research Group. Babson College, 231 Forest Street, Babson Park, MA 02457. Retrieved from https://files.eric.ed.gov/fulltext/ED572778.pdf

Alsofyani, M. M., Aris, B. B., Eynon, R., \& Majid, N. A. (2012). A preliminary evaluation of short blended online training workshop for TPACK development using the technology acceptance model. Turkish Online Journal of Educational TechnologyTOJET, 11(3), 20-32.

Bacow, L., Bowen, W., Guthrie, K., Lack, K., \& Long, M. (2015). Barriers to Adoption of Online Learning Systems in U.S. Higher Education. doi:10.18665/sr.22432

Banas, J. R., \& York, C. S. (2017). Pre-service teachers' Motivation to use technology and the impact of Authentic learning exercises. In L. Tomei (Ed.), Exploring the New Era of technology-infused Education (pp.121-140). Hershey, PA: IGI Global. doi:10.4018/978-1-5225-1709-2.ch008

Barin, M., Turgay, H. A. N., \& Şahin, S. A. R. I. (2018). Factors affecting teacher motivation and demotivational-reasoning in a second service area school in Turkey: A single-case research. Dil ve Dilbilimi Çalışmaları Dergisi, 14(4), 226-242. Retrieved from https://dergipark.org.tr/en/download/article-file/650778

Barton, R., \& Haydn, T. (2006). Trainee teachers' views on what helps them to use information and communication technology effectively in their subject teaching. Journal of Computer Assisted Learning, 22, 257-272. doi:10.1111/j.13652729.2006.00175.x

Boekaerts, M. (2001). Motivation, Learning, and Instruction. International Encyclopedia of the Social \& Behavioral Sciences, 10112-10117. doi:10.1016/b0-08-043076-7/024323.

Bolliger, D. U., \& Wasilik, O. (2009). Factors influencing faculty satisfaction with online teaching and learning in higher education. Distance Education, 30(1), 103-116. doi:10.1080/01587910902845949.

Burton-Jones, A., \& Hubona, G. S. (2005). Individual differences and usage behavior. ACM SIGMIS Database, 36(2), 58-77. doi:10.1145/1066149.1066155

ChanLin, L. J. (2005). Development of a Questionnaire for Determining the Factors in Technology Integration among Teachers. Journal of Instructional Psychology, 32(4), 287-292. Retrieved from https://www.learntechlib.org/p/98822/ 
Chapman, T. K. (2011). A critical race theory analysis of past and present institutional processes and policies in teacher education. In A. F. Ball \& C. A. Tyson (Eds.), Studying diversity in teacher education, 237-256. Rowman \& Littlefield Publishers Inc.

Cook, R. G., Ley, K., Crawford, C., \& Warner, A. (2009). Motivators and Inhibitors for University Faculty in Distance and e-learning. British Journal of Educational Technology, 40(1), 149-163. doi:10.1111/j.1467-8535.2008.00845.x

Cortina, J. M. (1993). Interaction, Nonlinearity, and Multicollinearity: implications for Multiple Regression. Journal of Management, 19(4), 915-922. doi:10.1177/014920639301900411

Davis, F. D. (1989). Perceived Usefulness, Perceived Ease of Use, and User Acceptance of Information Technology. MIS Quarterly, 13(3), 319. doi:10.2307/249008

Demetriadis, S., Barbas, A., Molohides, A., Palaigeorgiou, G., Psillos, D., Vlahavas, I., \& Pombortsis, A. (2003). "Cultures in negotiation": teachers' acceptance/resistance attitudes considering the infusion of technology into schools. Computers $\mathcal{E}$ Education, 41(1), 19-37. doi:10.1016/s0360-1315(03)00012-5

Ehlers, U.-D., \& Hilera, J. R. (2011). Special Issue on quality in e-learning. Journal of Computer Assisted Learning, 28(1), 1-3. doi:10.1111/j.1365-2729.2011.00448.x

Erkaya, O. R. (2012). Factors that motivate Turkish EFL teachers. International Journal of Research Studies in Language Learning, 2(1). doi:10.5861/ijrsll.2012.135

Ertmer, P. A., \& Ottenbreit-Leftwich, A. (2012). Removing obstacles to the pedagogical changes required by Jonassen's vision of authentic technology-enabled learning, Computer \& Education, 1-8. doi:10.1016/j.compedu.2012.10.008.

Gagné, M., \& Deci, E. L. (2005). Self-determination theory and work motivation. Journal of Organizational Behavior, 26(4), 331-362. doi:10.1002/job.322

Gardner, R. C., \& Lambert, W. E. (1972). Attitudes and Motivation in Second-Language Learning. Rowley, Mass.: Newbury House.

Ghenghesh, P. (2013). Job Satisfaction and Motivation - What Makes Teachers Tick? British Journal of Education, Society \& Behavioural Science, 3(4), 456-466. doi:10.9734/bjesbs/2013/5156

Glanz, J. (2014). Action research: An educational leader's guide to school improvement. Rowman \& Littlefield.

Graham, C. R. (2006). Blended learning systems: Definition, current trends, and future directions. In Handbook of blended learning: Global Perspectives, local designs. San Francisco, CA: Pfeiffer. $\quad$ Retrieved from http://www.click4it.org/images/a/a8/Graham.pdf

Green, T., Alejandro, J., \& Brown, A. H. (2009). The Retention of Experienced Faculty in Online Distance Education Programs: Understanding Factors that Impact their Involvement. The International Review of Research in Open and Distributed Learning, 10(3). doi:10.19173/irrodl.v10i3.683

Hadad, W. (2007). ICT-in-education toolkit reference handbook. InfoDev. Retrieved from http://www.infodev.org/en/Publication.301.html (accessed on 29 Dec 2019)

Hancock, S., \& Wong, T. (2012). Blended Learning. Retrieved from http://sites.wiki.ubc.ca/etec510/Blended_Learning\#cite_note-3 (accessed on 10 Sep 2019)

Han, J., \& Yin, H. (2016). Teacher motivation: Definition, research development, and implications for teachers. Cogent Education, 3(1). doi:10.1080/2331186x.2016.1217819

Herzberg, F., Mausner, B., \& Snyderman, B. B. (2017). Perspective. The Motivation to Work, 120-139. doi:10.4324/9781315124827-15 
Hettiarachchi, S. (2013). English Language Teacher Motivation in Sri Lankan Public Schools. Journal of Language Teaching and Research, 4(1). doi:10.4304/jltr.4.1.1-11

Jimoyiannis, A., \& Komis, V. (2007). Examining teachers' beliefs about ICT in education: implications of a teacher preparation program. Teacher Development, 11(2), 149173. doi:10.1080/13664530701414779

Johnson, D. T. (2000). Teaching mathematics to gifted students in a mixed-ability classroom. Reston, VA: ERIC Clearinghouse on Disabilities and Gifted Education. Retrieved from http://jukebox.esc13.net/estar34/estar34_d1_gifted_article.pdf

Kim, S. (2006). Public service motivation and organizational citizenship behavior in Korea. International Journal of Manpower, 27(8), 722-740. doi:10.1108/01437720610713521

King, W. R., \& He, J. (2006). A meta-analysis of the technology acceptance model. Information \& Management, 43(6), 740-755. doi:10.1016/j.im.2006.05.003

Lackey, K. (2011). Faculty development: An analysis of current and effective training strategies for preparing faculty to teach online. Online Journal of Distance Learning Administration, 14(4), 8- 17. Retrieved from https://ols.syr.edu/wpcontent/uploads/2012/04/Faculty-Development-An-Analysis-of-Current-andEffective-Training-Strategies-for-Preparing-Faculty-to-Teach-Online.pdf

Lee, J. (2001). Instructional support for distance education and faculty motivation, commitment, satisfaction. British Journal of Educational Technology, 32(2), 153-160. doi:10.1111/1467-8535.00186

Lee, Y., Kozar, K. A., \& Larsen, K. R. T. (2003). The Technology Acceptance Model: Past, Present, and Future. Communications of the Association for Information Systems, 12. doi:10.17705/1cais.01250

Lloyd, S. A., Byrne, M. M., \& McCoy, T. S. (2012). Faculty-perceived barriers to online education. Journal of online learning and teaching, 8(1). Available at https://jolt.merlot.org/vol8no1/abstracts.htm

Ma, W. W., Andersson, R., \& Streith, K.-O. (2005). Examining user acceptance of computer technology: an empirical study of student teachers. Journal of Computer Assisted Learning, 21(6), 387-395. doi:10.1111/j.1365-2729.2005.00145.x

Menyhárt A. (2008). Teachers or lecturers? The motivational profile of university teachers of English. Working Papers in Language Pedagogy, 2, 119-137. Retrieved from http://langped.elte.hu/WoPaLParticles/W2Menyhart.pdf

McQuiggan, C. A. (2012). Faculty Development for Online Teaching as a Catalyst for Change. Online Learning, 16(2). doi:10.24059/olj.v16i2.258

Oye.N.D, Salleh, M., \& Noorminshah. (2011). Knowledge Sharing in the Workplace: Motivators and Demotivators. International Journal of Managing Information Technology, 3(4), 71-84. doi:10.5121/ijmit.2011.3406

Panda, S., \& Mishra, S. (2007). E-Learning in a Mega Open University: Faculty attitude, barriers, and motivators. Educational Media International, 44(4), 323-338. doi:10.1080/09523980701680854

Ryan, R. M., \& Deci, E. L. (2000). Self-determination theory and the facilitation of intrinsic motivation, social development, and well-being. American Psychologist, 55(1), 68-78. doi:10.1037/0003-066x.55.1.68

Sansone N., Cesareni, D., Bortolotti, I., \& Buglass, S. (2019). Teaching technologymediated collaborative learning for trainee teachers. Technology, Pedagogy and Education, 28(3), 381-394. doi:10.1080/1475939X.2019.1623070.

Sansone, N., Cesareni, D., Ligorio, M. B., Bortolotti, I., \& Buglass, S.L., (2019). Developing knowledge work skills in a university course, Research Papers in Education, 35(1), 23-42.

doi:10.1080/02671522.2019.1677754 
Schechter, E. L. (2000). Factors relating to classroom implementation of computer technology in elementary schools (pp. 1-128). St. John's University (New York), School of Education and Human Services. Retrieved from https://www.learntechlib.org/p/123270/

Seaman, J. (2009). Online Learning as a Strategic Asset. Volume II: The Paradox of Faculty Voices--Views and Experiences with Online Learning. Results of a National Faculty Survey, Part of the Online Education Benchmarking Study Conducted by the APLU-Sloan National Commission on Online Learning. Association of Public and Land-Grant Universities. Retrieved from https://files.eric.ed.gov/fulltext/ED517311.pdf

Shea, P. (2019). Bridges and Barriers to Teaching Online College Courses: A Study of Experienced Online Faculty in Thirty- Six Colleges. Online Learning, 11(2). doi:10.24059/olj.v11i2.1728

Teddy So, K. K., \& Swatman, P. (2010). The Diminishing Influence of Age and Gender on the e-Learning Readiness of Teachers in Hong Kong. Lecture Notes in Computer Science, 477-488. doi:10.1007/978-3-642-14657-2_43

Teo, T., Lee, C. B., \& Chai, C. S. (2008). Understanding pre-service teachers' computer attitudes: Applying and extending the Technology Acceptance Model (TAM). Journal of Computer Assisted Learning, 24(2), 128-143. Doi:10.1111/j.13652729.2007.00247.x

Teo, T., Lee, C. B., Chai, C. S., \& Wong, S. L. (2009). Assessing the intention to use technology among pre-service teachers in Singapore and Malaysia: A multigroup invariance analysis of the Technology Acceptance Model (TAM). Computers \& Education, 53(3), 1000-1009. doi:10.1016/j.compedu.2009.05.017

Thatcher, J. B., Liu, Y., \& Stepina, L. P. (2002). The role of the work itself. Proceedings of the 2002 ACM SIGCPR Conference on Computer Personnel Research - SIGCPR '02. doi:10.1145/512360.512365

Venkatesh, V., \& Davis, F. D. (2000). A Theoretical Extension of the Technology Acceptance Model: Four Longitudinal Field Studies. Management Science, 46(2), 186-204. doi:10.1287/mnsc.46.2.186.11926

Vroom, V. H. (1964). Work and motivation. New York: Wiley. Retrieved from https:// psycnet.apa.org/record/1964-35027-000

Ward, M. E., Peters, G., \& Shelley, K. (2010). Student and faculty perceptions of the quality of online learning experiences. The International Review of Research in Open and Distributed Learning, 11(3), 57. doi:10.19173/irrodl.v11i3.867

Wingo, N. P., Ivankova, N. V., \& Moss, J. A. (2017). Faculty Perceptions about Teaching Online: Exploring the Literature Using the Technology Acceptance Model as an Organizing Framework. Online Learning, 21(1). doi:10.24059/olj.v21i1.761

Wong, K. T., Osman, R., Goh, P. S. C., \& Rahmat, M. K., (2013). Understanding Student Teachers' Behavioural Intention to Use Technology: Technology Acceptance Model (TAM) Validation and Testing. Online Submission, 6(1), 89-104. Retrieved from https:/ / files.eric.ed.gov/fulltext/ED539841.pdf 
Appendix A - List of constructs used in the study

Revised 10 item scale for perceived usefulness (Davis, 1989, Table 6, p. 329)

Item

No. Candidate item for psychometric measures for perceived usefulness

1 Using e-learning platform improves the quality of my teaching

2 Using an e-learning platform gives me greater control over my work

3 The E-learning platform enables me to accomplish tasks more quickly

4 The E-learning platform supports critical aspects of my work

5 E-learning platform increases my productivity

6 E-learning platform improves my job performance

7 The E-learning platform allows me to accomplish more work than would otherwise possible

8 The E-learning platform enhances my effectiveness on the work

9 E-learning platform makes it easier to do my work

10 Overall, I find the E-learning system useful in my work

Revised 10 item scale for perceived ease-of-use (Davis, 1989, Table 6, p. 329)

Item

No. Candidate item for psychometric measures for perceived usefulness

1 I find it burdensome to use the E-learning platform

2 Learning to operate an E-learning system is easy for me

3 Interacting with the E-learning system is often frustrating

4 I find it easy to get the E-learning system to do what I want it to do.

5 The E-learning system is rigid and inflexible to interact with.

6 It is easy for me to remember how to perform my tasks using an E-learning system

$7 \quad$ Interacting with the E-learning system requires a lot of my mental efforts.

8 My interaction with the E-learning system is clear and understandable

9 I find it takes a lot of efforts to become skillful at using an E-learning system

10 Overall, I find the E-learning system easy to use.

5 item scale developed for measuring Attitude towards technology (Ajzen and Fishbein, 1980)

\begin{tabular}{|c|c|}
\hline $\begin{array}{c}\text { Item } \\
\text { No. }\end{array}$ & All things considered, my using of E-learning is my job is :- \\
\hline 1 & Good ........ \\
\hline 2 & Wise ............ \\
\hline 3 & 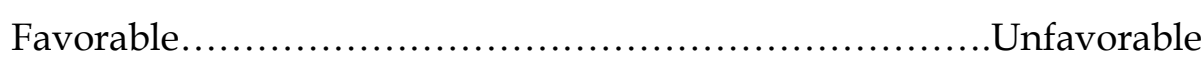 \\
\hline 4 & 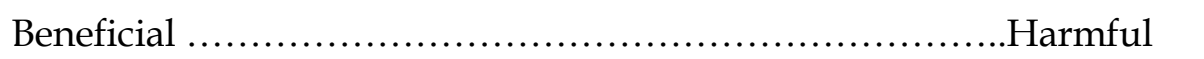 \\
\hline 5 & Positive \\
\hline
\end{tabular}

